\title{
OJCOSTWO DZIECKA NIESŁYSZĄCEGO Z PERSPEKTYWY PARADYGMATU EKOSYSTEMOWEGO
}

Współczesna dyskusja na temat ojcostwa dziecka niesłyszącego wyłania się z refleksji przedstawicieli teorii ekologicznych i teorii systemowych oraz z konstruktywnej analizy ludzkich doświadczeń. Chcąc wyjaśnić złożoność wielu zjawisk zachodzących w środowisku rodzinnym należy, odwołać się do paradygmatu ekologicznego (Bronfenbrenner, Morris, 2006) i systemowego (Świętochowski, 2014). Perspektywa ekologiczna uwzględnia wpływ wielu czynników środowiskowych (od najbliższego kontekstu mikro- po coraz bardziej odległe konteksty: egzo- i makrosystemowe) na funkcjonowanie człowieka jako członka rodziny. Z kolei paradygmat systemowy podkreśla znaczenie struktury rodziny, która organizuje sposoby i jakość interakcji między członkami rodziny a zewnętrznymi układami społecznymi.

\section{PARADYGMAT EKOSYSTEMOWY}

Idee współczesnych koncepcji ekosystemowych sięgają początku homo sapiens. Już w okresie starożytności filozofowie, lekarze interesowali się ekologią rodziny. Platon poszukiwał informacji, w jaki sposób ekosystemy dostarczają człowiekowi potrzebne do życia świadczenia ${ }^{1}$. Hipokrates, z którego imieniem

Dr hab. Katarzyna Plutecka, prof. UP - Wydział Pedagogiczny Uniwersytetu Pedagogicznego im. Komisji Edukacji Narodowej w Krakowie, adres do korespondencji: Wydział Pedagogiczny, ul. Ingardena 4, 30-060 Kraków; e-mail: plutecka@up.krakow.pl

${ }^{1}$ Platon zbadał interesujące fakty dziejące się w ekosystemie i dowiedział się, że wylesianie może doprowadzić do erozji gleby albo wysychania źródeł. 
wiąże się przysięga lekarska, jest uznawany za prekursorem ekologii². W dziele O powietrzu, wodach $i$ okolicach akcentował, jak istotne znacznie dla zdrowia człowieka ma środowisko, w którym żyje. Inny grecki myśliciel starożytnego świata Arystoteles, opierając się na dokonaniach Hipokratesa, również dostrzegł zależność człowieka od środowiska. Prekursorem myślenia w kategoriach ekologicznych był św. Franciszek z Asyżu - patron ekologów, który w średniowieczu udzielał rad drwalom, w jaki sposób ścinać drzewa, ogrodnikom doradzał, które trawy należy wycinać albo zostawić. Merytoryczna treść pojęcia „ekologia” została dookreślona dopiero w czasach nowożytnych ${ }^{3}$. W 1869 r. Ernst Haeckel był jednym z pierwszych uczonych, który zdefiniował ekologię (Ökologie) jako wiedzę o związkach organizmu ze środowiskiem. Dopiero Stephen Alfred Forbes doprecyzował jej zakres znaczeniowy, wyjaśniając, że ekologia jest to nauka biologiczna zajmująca się badaniem organizmów flory i fauny w środowiskach biotycznych i abiotycznych (Sak, 2006, s. 165). Amerykański ekolog Eugene Odum twierdził, że ekologia powinna odnosić się do całego środowiska, w którym człowiek żyje, zatem stanowi o jedności człowieka ze środowiskiem. Dlatego współcześnie człowiek jest postrzegany nie tylko jako osoba korzystająca z zasobów świata i przekraczająca granice świata przyrody, ale również jako jeden z wielu jej elementów, czyli całkowicie $\mathrm{i}$ integralnie w nią włączony ${ }^{4}$.

Paradygmat ekosystemowy należy rozważać zarówno z perspektywy przyrodniczej, jak i społecznej, bo każdy z nich wskazuje na konieczność opisu i wyjaśnienia procesów zachodzących w rodzinie $z$ innego punktu widzenia. Środowisko przyrodnicze tworzą właśnie ekosystemy rozumiane jako konkretne dynamiczne strukturalno-funkcjonalne układy przestrzenne złożone z biocenozy (świata żywego - roślin, zwierząt i mikroorganizmów) oraz biotopu (zespołu abiotycznych warun-

\footnotetext{
${ }^{2}$ Jeden z aforyzmów Hipokratesa brzmiał: „Lekarz leczy, natura uzdrawia”. Wśród wielu jego zasług dla medycyny warto wspomnieć typologię temperamentów powiązanych $\mathrm{z}$ naturalnym środowiskiem człowieka. Hipokrates przystosował typy ludzkie do czterech stron świata i z nimi też powiązał cztery podstawowe własności przyrody: suchość, wilgotność, ciepło i zimno. Stąd i cztery następujące typy temperamentów człowieka: sangwinik (przeważa krew, ciepło oraz wilgotność), choleryk (natura sucha), flegmatyk (natura wilgotna) i melancholik (natura zimna).

${ }^{3}$ Słowo ekologia pochodzi z greckiego słowa oikos, oznacza dom, miejsce do życia, gospodarstwo oraz gospodarowanie. W kontekście analizy znaczenia etymologicznego słowa „ekologia” warto przypomnieć tezę Doroty Kornas-Bieli (2000). Autorka dowodzi, że skoro oikos oznacza dom, to pierwszym domem, w którym mieszka dziecko, jest łono matki. Łono matki stanowi więc pierwszy naturalny ekosystem człowieka.

${ }^{4}$ Autorzy próbują wyjaśnić funkcjonowanie człowieka poprzez odwołanie do określonej teorii (hipotezy) biologicznej, np.: do czynników płciowych, kulturowych lub etnicznych (Goldenberg, Goldenberg, 2006). Jednakże uznano, że człowiek jakościowo zupełnie się nie różni od innych istot żywych, a wszelkie różnice mają wyłącznie charakter ilościowy.
} 
ków środowiska), a wyrażające jedność świata organicznego i środowiska przy określonym składzie komponentów (Matuszkiewicz, 2001). Oznacza to, że każdy ekosystem zależnie od swojej specyfiki cechuje się określonymi składowymi, które wpływają na jego funkcjonowanie, strukturę i procesy. Ekologia rodziny ma odniesienie do aksjologii, ponieważ wyznacza określoną jakość życia ${ }^{5}$. Jest ona związana z realizacją określonego systemu wartości, zaspokojeniem potrzeb, kształtowaniem umiejętności koniecznych w codziennym funkcjonowaniu społecznym (zgodnie z naturą człowieka).

Perspektywę społeczną tworzą natomiast ludzie, których dobrostan (fizyczny, psychiczny i duchowy) zależy od korzyści uzyskiwanych ze świadczeń dostarczanych przez ekosystemy. W niniejsze ujęcie wpisuje się cebulowa teoria szczęścia (dobrostanu), opracowana przez Janusza Czapińskiego (2004) na początku lat dziewięćdziesiątych XX wieku. Autor wprowadził pojęcie „cebuli dobrostanu”, rozumiane jako mechanizm psychologiczny, który pomaga wyjaśniać zależności między subiektywnym poczuciem szczęścia a zewnętrznymi okolicznościami oraz cechami osobowości człowieka. Według twórcy teorii istnieją trzy poziomy (warstwy) szczęścia i są to: wola życia, ogólny dobrostan subiektywny, a także satysfakcje cząstkowe, dające zadowolenie z poszczególnych dziedzin życia. Najgłębszą warstwą i jednocześnie odporną na zmiany jest wola życia. Na tym podstawowym poziomie dobrostan oznacza pozytywne nastawienie wobec celów, które człowiek chce realizować i które nadają sens jego życiu. Kolejny poziom szczęścia tworzy ogólny dobrostan subiektywny, czyli świadoma ocena przez osobę jej własnego życia. Jednakże odczucia i oceny dotyczące własnego szczęścia mogą się zmieniać pod wpływem różnych, często nieplanowanych okoliczności życiowych. Zadowolenie z jakiejś konkretnej dziedziny życia, np. pożycia małżeńskiego, pracy zawodowej, zdrowia, warunków mieszkaniowych czy życia towarzyskiego, jest najbardziej zmienne i zależne od czynników zewnętrznych. Koncepcja ta w dużej mierze pomaga zrozumieć, dlaczego niektóre osoby umieją radzić sobie z sytuacjami kryzysowymi, a inne, mimo ogólnej satysfakcji życiowej, stale nie są zadowolone z siebie i swoich życiowych osiągnięć.

Początek ogólnej teorii systemu przypada na lata trzydzieste XX wieku za sprawą biologa i filozofa Ludwiga von Bertalanffy'ego. Koncepcja niniejsza sprowadza się do trzech głównych tez. System tworzy zbiór zdolnych do funkcjonowania elementów, między którymi zachodzą wzajemne, dynamiczne

\footnotetext{
${ }^{5}$ Włodzimierz Fijałkowski (2011, s. 92) również sygnalizuje, że ekologia ma odniesienie do aksjologii. Dlatego, że życie człowieka jest traktowane jako podstawowa wartość, a środowisko społeczno-przyrodnicze jako wspólne dobro.
} 
relacje i sprzężenia. Jeżeli system traktuje się jako integralną całość, to oznacza, że wchodzące $\mathrm{w}$ jego skład obiekty i ich atrybuty należy rozpatrywać z punktu widzenia funkcji, jaką mają przypisaną w systemie. Granice systemu określają jego tożsamość w czasie i w przestrzeni (Świętochowski, 2014, s. 22). Na przełomie lat siedemdziesiątych i osiemdziesiątych XX wieku paradygmat ekosystemowy dotarł do nauk społecznych i od tego czasu naukowcy rozpoczęli ekologiczne interpretacje funkcjonowania środowiska rodzinnego. Urie Bronfenbrenner (1993) zajął się relacjami między dzieckiem a szeroko rozumianym środowiskiem, tworząc teorię systemów ekologicznych lub inaczej - ekologiczną teorię rozwoju. Opierając się na powyższej teorii, należy stwierdzić, że człowiek żyje w rozmaitych środowiskach społecznych, które nakładają się na siebie. Zasadniczą częścią ekologicznej teorii Urie Bronfenbrennera są cztery podstawowe elementy: „Proces - Człowiek - Kontekst - Czas”. W zakresie kontekstów rozwoju człowieka, czyli środowisk, autor wyróżnił najpierw cztery podsystemy: mikrosystem, mezosystem, egzosystem i makrosystem (Bronfenbrenner, 1993), a w dalszych dociekaniach naukowych dodał jeszcze chronosystem (Bronfenbrenner, Morris, 2006, s. 996) ${ }^{6}$. Według autora tej teorii rodzina stanowi kompleksowy system, w którym ważne miejsce ma przestrzeganie określonych zasad jego funkcjonowania przez każdego członka, np. troszczenie się o pamięć wspólnej historii, silne więzi uczuciowe czy poczucie lojalności. Pielęgnowanie tych i innych zasad gwarantuje równowagę ekologiczną. Rodzina to podstawowe i najbliższe środowisko życia człowieka, które jest powiązane sprzężeniem zwrotnym z wieloma systemami społecznymi. Zdaniem Herberta Goldenberg, Irene Goldenberg (2006) podejście ekosystemowe jest spojrzeniem wymagającym współpracy i ciągłego przepływu informacji w obu kierunkach (na zewnątrz i do wewnątrz).

Teoria systemów ekologicznych pozwala więc na definiowanie rodziny bardzo szeroko. Rozpoczynając od mikrosystemu, czyli podstawowych relacji w podsystemie dziecko a rodzic, poprzez dwustronne powiązania z udziałem obojga rodziców i ich dziecka, aż po bogatą sieć interakcji i podleganie wpływom jednego lub więcej większych systemów w społeczeństwie. Powyższe ujęcie interdyscyplinarne wzbogaciło kontekst ewolucyjny i socjologiczny zachowań

\footnotetext{
${ }^{6}$ Mikrosystem jest to ta część środowiska, o określonych właściwościach fizycznych i materialnych, z którym człowiek pozostaje w bezpośrednich relacjach. Mezosystem obejmuje te mikrosystemy, z którymi rodzina nawiązuje wzajemne relacje. Kolejny kontekst społeczny to egzosystem, czyli jeden lub więcej subsystemów osadzonych w makrosystemie. Oddziaływania między egzosystemem a mezosystemem są ograniczone, bo mają wymiar jednokierunkowy. Makrosystem obejmuje szeroko rozumianą kulturę, którą tworzą wytwory materialne i niematerialne. Wymiar czasowy rozwoju człowieka wyznacza chronosystem.
} 
społecznych człowieka. Okazuje się bowiem, że różne struktury i systemy środowiskowe stanowią siłę napędową oraz źródła zmian w rozwoju człowieka.

\section{OJCOSTWO}

Ojcostwo jest pojęciem interdyscyplinarnym i stanowi przedmiot głębokich dociekań na gruncie nauk humanistycznych, społecznych czy przyrodniczych. Bronisław Malinowski (2005) stwierdził, że ojcostwo jest jednym z czynników tworzących ludzką cywilizację. Ten wybitny socjolog i antropolog dokonał ważnego odkrycia, które nazwał zasadą legitymizacji. Otóż cechą wspólną kultur jest wysiłek społeczeństwa, by rodzic uznawał własne potomstwo. To społeczeństwo przekazuje zasadę, że każde dziecko posiada odpowiedzialnego ojca z punktu widzenia moralnego i prawnego. Z kolei ojciec ma obowiązek uznać swoje dziecko i pomagać matce w opiece, wychowaniu nad nim. Ojciec jest więc zobowiązany zapewnić biologiczne przetrwanie potomstwa, a także przygotować je do samodzielnego funkcjonowania. Porównawcze badania dotyczące ewolucji zachowań człowieka i szympansów wykazały, że ojcostwo jest ,jednym spośród wielu nowych osiągnięć filogenetycznych człowieka" (Eibl-Eibesefedt, 1999; za Petri, 2012, s. 30). Fakt ten wskazuje wyraźnie na aspekt ekologiczny ojcostwa ${ }^{7}$.

Psychologowie, filozofowie podkreślają, że istnieje związek lub wzajemne relacje i odniesienia między ojcem a dzieckiem (dziećmi), ojcem dziecka a matką dziecka, a także relacje do Boga stwórcy (w przypadku osób wierzących) (Kłys, 1999, s. 138; Meissner, 2001, s. 193; Nagórny, 2001, s. 75; Kasprzak, 2004, s. 5; Baran, 2006, s. 27). W ujęciu Wandy Półtawskiej (2001, s. 225) ojcostwo świadczy o dojrzałości męskiej i wymaga od mężczyzny przygotowania się do roli rodzica, bo tylko wtedy będzie świadome i odpowiedzialne. W niniejszym znaczeniu można dostrzec tę szczególną funkcję mężczyzny oznaczającą: przyjęcie właściwego miejsca w małżeństwie i w rodzinie, poczęcie dziecka, troskliwą miłość wobec potomstwa, utrzymanie i wyżywienie członków rodziny oraz wychowanie dziecka (Mierzwiński, 1999, s. 68). Niektórzy autorzy postrzegają ojcostwo w wymiarze religijnym i wyjaśniają, że ludzkie ojcostwo jest misją, powołaniem (Świerczek, 2010), urzeczywistnieniem człowieczeństwa (Kłys, 1999, s. 135), darem od Boga (Wójcik, 1999). Łatwo zauważyć, że duchowych

\footnotetext{
${ }^{7}$ Obserwacja zachowań szympansów przez Ireneusza Eibl-Eibesefedta (1999; za Petri, 2012) pozwoliła na sformułowanie tezy, że oboje rodzice zajmują się potomstwem i dzielą się swoimi obowiązkami.
} 
korzeni ojcostwa dostarcza wiara, która odzwierciedla poszukiwanie przez człowieka celu w życiu codziennym. Wartości duchowe są przecież jednym z podstawowych czynników wpływających na postawy i przekonania rodziców. Analiza istoty ojcostwa $\mathrm{w}$ dużym stopniu wiąże sie $\mathrm{z}$ rozważaniami na temat męskości (Pulikowski, 2001, s. 96). Ojcostwo jest miarą jakości mężczyzny, który posiada dziecko. Warto też pamiętać, że ojcostwo ma charakter procesualny, rozwija się etapami. Styl wychowawczy ojca jest związany z etapami cyklu życiowego jego dziecka, a więc swoistością wymagań kolejnych okresów rozwojowych, o czym pisze Osvaldo Poli (2008, s. 69). „W pierwszej fazie życia to właśnie postać matki dostosowuje się pod wieloma względami najlepiej do rodzaju potrzeb, jakie ma maleńkie dziecko [...]. Ojciec ma możliwość wzbogacenia i wysubtelnienia swojej wrażliwości, pozwalając się kierować wrażliwości matczynej, aby dotrzeć z lepszym przygotowaniem do tego, co będzie się działo później i co będzie się wiązało z jego większym zaangażowaniem w relację wychowawczą". Życie rodzinne podlega przejściowym zmianom, zgodnie z przebiegiem cyklu życia. Ciągłość i zmienność to cechy, które należy również przypisać ojcostwu.

Na przestrzeni wieków obraz ojca ulegał ewolucji - od tradycyjnego, patriarchalnego żywiciela, głowy rodziny i srogiego wychowawcy do nowego modelu: opiekuna, partnera dziecka. Jeszcze w latach osiemdziesiątych minionego wieku ojcowie byli opisywani jako ,zapomniani towarzysze w rozwoju dziecka” (Lamb, 1975). Ten krytyczny nurt badań nad ojcostwem spowodował, że ojciec jako rodzic był nieobecny, zagubiony, wręcz pozbawiony autorytetu. Wyuczone wzorce zachowań w epoce pre/inter/postindustrialnej nakładały na mężczyznę symboliczne brzemię patriarchy. Aleksander Mitscherlich, publikując w 1963 r. książkę Ku społeczeństwu bez ojców, sygnalizował nasilający się problem kryzysu ojcostwa (za Petri, 2012, s.12). Autor udowodnit, że autorytet ojca nie jest zjawiskiem naturalnym i bez pracy dla dobra rodziny ulega rozpadowi, a ojciec traci tym samym siłę swojego oddziaływania i szacunek. Refleksja nad znaczeniem udziału ojca w wychowaniu dziecka wymagała badań interdyscyplinarnych, aby docenić niepowtarzalny wymiar relacji między ojcem a dzieckiem.

Współcześnie wielu autorów podkreśla pozytywny wymiar ojcostwa i docenia jego swoisty wkład dla rozwoju dziecka (Kłys, 1999; Mierzwiński, 1999; Meissner, 2001; Nagórny, 2001; Kasprzak, 2004; Baran, 2006; Świerczek, 2010). Zdaniem Małgorzaty Sitarczyk (2002) współczesne badania dotyczące ojcostwa można podzielić na dwa główne nurty. Pierwszy z nich opisuje znaczenie ojca w opiece nad dzieckiem poprzez akcentowanie potrzeby tych oddziaływań dla rozwoju intelektualnego, społecznego, moralnego i emocjonalnego dziecka. 
W drugim nurcie analiz empirycznych autorzy koncentrują się na skutkach natury psychicznej i psychospołecznej u dzieci, spowodowanych niezaspokojeniem potrzeby więzi z ojcem, jego nieobecnością fizyczną lub/i psychiczną czy nieprawidłowymi postawami ojcowskimi.

Podjęta refleksja naukowa nad znaczeniem prawdziwego ojcostwa pozwoliła na wypracowanie realistycznej wizji roli ojca, poznanie męskiej wrażliwości oraz stylu wychowawczego. Trzeba jednak zaznaczyć, że do wychowania dziecka potrzebny jest ojciec, a nie nosiciel roli wyznaczonej przez kulturę albo religię. Zdaniem Steve Biddulpha (2011, s. 83-85) pierwszym krokiem na drodze do dobrego ojcostwa było odrzucenie starych, tzw. toksycznych wzorów z przeszłości. Autor omawia cztery kategorie „wadliwych ojców”, które były wzorcami osobowymi w minionych epokach, są to: niedoszły król, ojciec krytyczny, ojciec bierny i ojciec nieobecny

Ważne znaczenie dla omawianej problematyki miało zdiagnozowanie różnic w stylu wychowawczym matek i ojców, którzy charakteryzują się cechami przeważającymi, a nie obecnością lub brakiem określonych cech osobowości, związanych z typowym sposobem bycia dla kobiety i dla mężczyzny. Każdy z rodziców ujawnia cechy typowo kobiece i typowo męskie, zgodnie ze znamienną przewagą dla płci biologicznej ${ }^{8}$. Badania dotyczące kształtowania się relacji między ojcem a dzieckiem pozwoliły uzasadnić fakt, że ojciec w takim samym stopniu jak matka dysponuje biologicznie uwarunkowanym systemem zachowań eksploracyjnych (Petri, 2012, s. 31). Jednakże ojciec, wchodząc w relacje osobowe z dzieckiem, zachowuje się inaczej niż matka, nawet jeżeli stara się być wyrozumiały, troskliwy, to i tak jest ,inny”, czyli jedyny w swoim rodzaju. $\mathrm{Na}$ styl wychowawczy ojca składa się jego charakter, dojrzałość emocjonalna, osobiste doświadczenia życiowe, system wartości. Matki i ojcowie uzupełniają się. Jeżeli tworzą zgodny zespół, to wtedy ich dziecko otrzymuje to, czego potrzebuje. Jeśli jednak jeden z rodziców jest nieobecny, to dziecko na tym traci. Badania wykazują, że ojcowie poprzez odpowiednie interakcje mikrosystemowe nie tylko wpływają na dziecko, ale również oddziałują na zachowania matki (Lamb, Pleck, Levine, 1985; Cummings, O’Reilly, 1997; Lundy, 2002). Relacja małżeńska jest czynnikiem determinującym relację rodzic-dziecko i w konsekwencji kształtuje poczucie więzi między ojcem a dzieckiem. Dlatego tak istotne znaczenie dla

\footnotetext{
${ }^{8}$ Nastąpiła relatywizacja tradycyjnych granic wyznaczanych przez płeć. Męskość i kobiecość nie są wyłącznie cechami psychologicznymi, związanymi z płcią biologiczną. Już Carl Gustav Jung zakładał obecność animusa (pierwiastka męskiego) i animy (pierwiastka żeńskiego) u osób obu płci.
} 
prawidłowego rozwoju dziecka ma współpraca między rodzicami i zrównoważenie macierzyństwa $\mathrm{z}$ ojcostwem.

\section{OJCOSTWO DZIECKA NIESŁYSZĄCEGO}

W końcu ubiegłego stulecia ojcostwo dziecka niesłyszącego było określane jako problem zapomniany, wręcz zignorowany (Crowley, Keane, Needham, 1982). Współcześnie podjęte badania i wynikające z nich refleksje naukowe nad znaczeniem udziału ojca $\mathrm{w}$ wychowaniu czy rehabilitacji dziecka niesłyszącego mają pokazać swoistość sytuacji rodzinnej i konieczność włączenia sieci wsparcia społecznego. Fakt posiadania dziecka niesłyszącego powinien być doświadczeniem życiowym, które reorganizuje, ale nie zaburza funkcjonowania mikrosystemu. Dlatego tak istotne znaczenie ma uaktywnienie wewnętrznych mechanizmów adaptacyjnych rodziny. Rodzice i inni członkowie rodziny powinni zrozumieć, że ta nowa sytuacja życiowa wymaga częściowo zmian związanych $\mathrm{z}$ funkcjonowaniem wszystkich członków systemu. Proces zmian rozpoczyna się od najbliższego środowiska społecznego, w którym każdy z członków rodziny podejmuje aktywność. W procesie zmian ważne będzie wspólne realizowanie określonych celów przy jednoczesnym zaspokojeniu indywidualnych potrzeb. W obliczu zadania kryzysowego ${ }^{9}$ siła więzi rodzinnych powinna być jednym z czynników integrujących i nienaruszających naturalnego systemu rodziny. Związki pomiędzy członkami rodziny będą głębokie i wielopoziomowe jeżeli zostaną oparte na silnych, trwałych i wzajemnych więziach uczuciowych oraz poczuciu lojalności (Goldenberg, Goldenberg 2006, s. 3). Bliskie relacje łączące członków rodziny, ich jakość, a szczególnie trwałość i elastyczność są czynnikami ich umacniającymi.

Działania opiekuńcze, wychowawcze ojca są związane z jakością relacji, jaką kształtuje on ze swoją żoną - matką dziecka niesłyszącego. Jest to relacja o charakterze interakcyjnym, która skutkuje na zachowania obojga rodziców. $\mathrm{Z}$ badań jakościowych wynika, że matki dzieci niesłyszących ujawniają brak

\footnotetext{
${ }^{9}$ W myśl założeń twórców Modelu McMaster sprawnie funkcjonujący system rodzinny ma do realizacji trzy grupy zadań. Pierwsza grupa zadań to zadania podstawowe, które koncentrują się wokół zapewnienia członkom rodziny odpowiednich warunków do życia. Kolejna, druga grupa to zadania rozwojowe, związane z zaspokojeniem potrzeb poszczególnych członków rodziny, które wynikają $\mathrm{z}$ ich cyklu życia. Ostatnia, trzecia grupa to właśnie zadania kryzysowe, dotyczące prawidłowego kierowania zasobami rodzinnymi w szczególnie trudnych sytuacjach, które mogą być spowodowane: chorobą, wypadkiem członka rodziny, a także ograniczeniami rozwojowymi czy niepełnosprawnością sensoryczną dziecka (Miller, Ryan, Keitner, Bishop, Epstein, 2000).
} 
zainteresowania pogłębianiem więzi emocjonalnych z mężem (Zalewska, 1998). Jest to związane z reakcjami psychicznymi i przeżyciami, które ujawnia matka na informacje o uszkodzeniu słuchu dziecka. Dynamika relacji małżeńskich będzie więc uzależniać efektywność oddziaływań ojca na dziecko niesłyszące. Ojciec dysponuje zdeterminowanym biologicznie programem eksploracyjnym i dlatego może też pełnić funkcję buforową, wspierać matkę i sprzyjać dążeniom poznawczym i rozwojowym dziecka. Z kolei obecność fizyczna i psychiczna ojca, jego bliski uczuciowo związek i emocjonalne wsparcie wobec żony - matki dziecka niesłyszącego ułatwiają jej proces adaptacji do uszkodzenia słuchu dziecka i mogą zmniejszyć poziom stresu macierzyńskiego (Calderon, Low, 1998). W tych nowych wyzwaniach życiowych ojcostwo dziecka niesłyszącego zmieni swoją tożsamość i będzie wymagało ponownego przemyślenia i zmodyfikowania obowiązków rodzinnych. Ważne będą decyzje, podejmowane wspólnie z żoną, związane z określeniem i podziałem opieki nad dzieckiem niesłyszącym, a także w zakresie pracy, zarobków. Ojciec-mąż musi być też świadomy (pomimo mniejszej ilości wolnego czasu), że powinien nadal pielęgnować swój związek małżeński, wspólnie spędzać czas i być razem z żoną. Tworzenie tych wspólnych doświadczeń jest sztuką uczenia się współpracy, zawierania kompromisów między potrzebą bycia razem a postawą budowania poczucia własnej wartości.

Rodzina, w której jest dziecko niesłyszące, jest wręcz zmuszona do częstszych kontaktów z innymi, większymi systemami społecznymi i podlegania ich wpływom. Rozpoczęcie przez dziecko niesłyszące procesu rehabilitacji, a później edukacji oznacza dla rodziców konieczność nawiązywania i utrzymywania kontaktów ze specjalistami, instytucjami każdego z poziomów prezentowanych w modelu ekosystemowym. Podejmowane w tych sprawach decyzje, formy wspomagania rozwoju dziecka/ucznia niesłyszącego będą wynikać nie tylko z bezpośredniej sytuacji, związanej z indywidualnymi potrzebami rozwojowymi i edukacyjnymi, ale będą też uzależnione od kontekstu prawnego, społecznego, które stwarza środowisko życia konkretnej rodziny. Warto przypomnieć, że to właśnie ojcowie byli nie tylko inicjatorami dostępu dzieci niesłyszących do szkół, ale też pierwszymi partnerami edukacyjnymi swoich dzieci ${ }^{10}$. Obecnie ojcowie są traktowani jako partnerzy specjalistów, ponieważ mogą zapewnić ciągłość procesów wychowania i rehabilitacji ich dziecka. W myśl założeń podejście ekosystemowe jest przedsięwzięciem wymagającym współpracy. Mężczyzna sam siebie nie kształtuje. Jedną z dostrzeganych zmian społecznych jest uaktywnienie się rodziców,

${ }^{10}$ Źródła historyczne podają liczne przykłady zaangażowania się słyszących ojców w edukację ich głuchych dzieci na terenach należących do Stanów Zjednoczonych (zob. Plutecka, 2017). 
aby poznawać trudności, jakie mogą napotykać ich niesłyszące dzieci i jednocześnie móc wpływać na ich losy. Dlatego istnieje potrzeba organizowania się ojców w stowarzyszenia czy organizacje w skali lokalnej albo krajowej. Przynależność do takiej społeczności czy wspólnoty ojców dzieci niesłyszących ma nie tylko charakter praktyczny czy informacyjny. Spotkania i rozmowy z osobami, które doświadczyły podobnych problemów życiowych, są też dla nich formą wsparcia. Ojcowie dzieci niesłyszących potrzebują pomocy specjalistów i tych osób z grup wsparcia, które znalazły się w podobnej dla siebie sytuacji. Wspólne rozwiązywanie problemów, wzajemne motywowanie się są czynnikami wzmacniającymi poczucie sprawstwa.

Ojcostwo dziecka niesłyszącego ma charakter rozwojowy i wymaga uwzględnienia czynnika czasu. Chronosystem wyznacza czasowy wymiar rozwoju poszczególnych członków rodziny. Ojciec, wchodząc w interakcje z dzieckiem niesłyszącym, tworzy sieć wzajemnych kontaktów, które stopniowo zmieniają się w trakcie kolejnych cyklów życia. Po drodze, podczas następujących po sobie etapów życia rodzinnego, czekają na ojca do wypełnienia następne zadania rozwojowe. Dlatego tak ważna jest koncentracja na dziecku, które nie słyszy. Istotne znaczenie ma intensywne wspomaganie rozwoju i zwrócenie uwagi na jego kontekst, w którym zachodzą wspólne interakcje między ojcem a dzieckiem niesłyszącym. Uczestnicząc w tych interakcjach, ojciec wpływa nie tylko na harmonijny rozwój fizyczny, poznawczy, społeczny i emocjonalny swojego niesłyszącego dziecka, ale również stymuluje jego indywidualny potencjał rozwojowy. Fakt uszkodzenia słuchu powoduje u dziecka dodatkowe trudności związane z porozumiewaniem się. Warto przywołać badania Marii Kielar-Turskiej (1992, s. 325). Autorka zaakcentowała inny wymiar interakcji językowych ojca z dzieckiem. Ich kontakt językowy z dzieckiem ma charakter aktywizujący i stymulująco pobudza rozwój języka dziecka. Ojcowie przede wszystkim rozkazują, stosują trudniejsze artykulacyjnie konstrukcje składniowe i wprowadzają do zasobu językowego trudniejsze słowa, stawiają zróżnicowane pytania, np.: kiedy, gdzie, jak, dlaczego? Przyjęty przez ojca sposób komunikowania się dorosłego z dzieckiem niesłyszącym będzie też uzależniony od jego postawy dotyczącej wyboru metody komunikacji: migowej czy oralnej. 


\section{REFLEKSJE KOŃCOWE}

Przyjęcie ekosystemowego wymiaru ojcostwa dziecka niesłyszącego skłania do refleksji dotyczącej uwzględnienia w określonym kontekście znaczenia czynników wewnątrzrodzinnych i zewnętrznych dla funkcjonowania rodziny. Podejmowane działania ojca przebiegają więc w różnorodnych kontekstach społecznych, zgodnie z którymi rozwija się on i zmienia dzięki charakterowi oraz sile związków łączących go z otoczeniem. Jest to proces, który dokonuje się w systemie różnych przestrzeni i jest efektem zachodzących interakcji społecznych. Takie ujęcie umożliwia poszukiwanie w poszczególnych kontekstach społecznych źródeł i czynników kształtujących ojcostwo. Dlatego tak trudne jest wypracowanie modelu ojcostwa dziecka niesłyszącego we wciąż zmieniających się, nowych warunkach życia rodzinnego. Dynamika i różnorodność zachowania się ojca, indywidualne doświadczenia budują kontekst rozwojowy. Należy przyjąć, że ojcostwo dziecka niesłyszącego jest czymś naturalnym dla człowieka funkcjonującego w mikrosystemie, a także wyrazem zrozumienia potrzeb wszystkich członków rodziny. Siła prawdziwego ojcostwa polega więc na tym, że ojciec jest źródłem wsparcia dla bliskich w trudnych sytuacjach życiowych, źródłem doświadczeń, które mają znaczenie dla rozwoju psychospołecznego dziecka niesłyszącego i jego indywidualnego rozwoju.

\section{BIBLIOGRAFIA}

BARAN, S. (2006). Przywrócić wartość ojcostwa. Kwartalnik Edukacyjny, 3, 22-31.

Biddulph, S. (2011). Męskość. Przeł. A. Jacewicz. Poznań: Dom Wydawniczy REBIS.

BRONFENBRENNER, U. (1993). The ecology of cognitive development: Research models and fugitive findings. W: R. WOZNIAK, K. FisCHER (eds.), Development in context: Acting and thinking in specific environments (s. 3-44). Hillsdale, NJ: Erlbaum.

BronfenBRENNER, U., MORRIS, P.A. (2006). The bioecological model of human development. W: W. DAMON, R.M. LERNER (eds.), Handbook of child psychology, vol. 1, Theoretical models of human development $\left(6^{\text {th }}\right.$ ed.) (s. 793-828). New York: John Wiley.

CALDERON, R., Low, S. (1998). Early social-emotional, language, and academic development in children with hearing loss: families with and without fathers. American Annals of the Deaf, 143(3), 225-234.

Crowley, M., Keane, K., Needham, C. (1982). Fathers: The Forgotten Parents. American Annals of the Deaf, 127, 38-40.

CzAPIŃsKi, J. (2004). Psychologiczne teorie szczęścia. W: J. CZAPIŃsKi i In. (red.), Psychologia pozytywna. Nauka o szczęściu, zdrowiu, sile i cnotach czlowieka (s. 51-102). Warszawa: PWN.

Cummings, E.M., O'ReILly, A.W. (1997). Fathers in family context: Effects of marital quality on child adjustment. W: M.E. LAMB (ed.), The role of the father in child development (s. 49-65). Hoboken, NJ, US: John Wiley \& Sons Inc. 
FiJAŁOWSKI, W. (2011). Ekologia rodziny. Ekologiczna odnowa prokreacji. Kraków: Wydawnictwo Rubikon.

Goldenberg, H. Goldenberg, I. (2006). Terapia rodzin. Przeł. M. Łuczak, M. Młynarz, K. Siemieniuk. Kraków: Wydawnictwo UJ.

KASPRZAK, T. (2004). Tajemnica ojcostwa. Niebieska Linia, 1, 3-6.

KIElar-Turska M. (1992). Dziecko i komunikacja. Jak dziecko staje się kompetentne komunikacyjnie? Wychowanie w przedszkolu, 6, 320-330.

KŁYS, J. (1999), Jak rozumiem ojcostwo. Studia nad Rodzina, 3(2), 133-144.

KornAs-Biela, D. (2000). Ekologia tona ekologia świata. O nowy paradygmat w ekologii. W: Dołęga J.M., Czartoszewski J.W. (red.), Ekologia rodziny ludzkiej (s. 103-105). Olecko: Wydawnictwo Wszechnicy Mazurskiej.

Lamb, M.E. (1975). Fathers: Forgotten contributors to child development. Human Development, 18(4), 245-266.

Lamb, M.E., Pleck, J.H., LeVine, J.A. (1985). The role of the father in child development: The effects of increased paternal involvement. W: B.B. LAHEY, A.E. KAZDIN (eds.), Advances in clinical child psychology (vol. 8, s. 229-266). New York: Plenum.

Lundy, B.L. (2002). Paternal socio-psychological factors and infant attachment: The mediating role of synchrony in father-infant interactions. Infant Behavior \& Development, 25(2), 221-236.

Malinowski, B. (2005). Malżeństwo, pokrewieństwo, W: A. Mencwel (red.) Antropologia kultury. Zagadnienia i wybór tekstów (s. 303-334). Warszawa: Wydawnictwo Uniwersytetu Warszawskiego.

Matuszkiewicz, W. (2001). Przewodnik do oznaczania zbiorowisk roślinnych Polski. Warszawa: Wydawnictwo Naukowe PWN.

MEISSNER, K.W. (2001). Ojciec - potrzeby dziecka a wzorzec męski. W: D. KoRNAS-BIELA (red.), Oblicza ojcostwa (s. 193-199). Lublin: Towarzystwo Naukowe KUL.

MiERZwiŃSKI, B. (1999). Mężczyzna istota nieznana. Warszawa: Oficyna Wydawniczo-Poligraficzna „ADAM”.

Miller, I.W., Ryan, C.E., Keitner, G.I., Bishop, D.S., Epstein, N.B. (2000). The McMaster Approach to Families: Theory, Assessment, Treatment and Research, Journal of Family Therapy, 22(2), 168-189.

NagóRny, J. (2001). Posłannictwo ojca w kontekście wspótczesności. W: D. Kornas-BIELA (red.), Oblicza ojcostwa (s. 59-81). Lublin: Towarzystwo Naukowe KUL.

Petri, H. (2012). Dramat braku ojca. Poznań: Flos Carmeli.

PluteckA, K. (2017). Z historii edukacji osób głuchych mieszkających na terenach należących do Stanów Zjednoczonych. Rocznik Komisji Nauk Pedagogicznych, LXIX, 5-13.

Poli, O. (2008). Serce taty. Niezbędnik każdego ojca. Przeł. E. Łukaszyk, Kraków: Wydawnictwo WAM.

PóŁtawska, W. (2000). Ojcostwo - los czy wybór? Wychowawca, 5, 6-9.

Pulikowski, J. (2001). Czy w dzisiejszych czasach warto być ojcem. W: D. Kornas-Biela (red.), Oblicza ojcostwa (s. 95-124). Lublin: Towarzystwo Naukowe KUL.

SAK, J. (2006). Rozważania o ekofilozofii: od ekologii do astheneologii. Diametros, 9, 165-172.

SitARCZYK, M. (2002). Międzypokoleniowa transmisja postaw wychowawczych ojców. Lublin: Wydawnictwo UMCS.

ŚWIĘTOCHOwSKI, W. (2014). Rodzina w ujęciu systemowym. W: I. JANICKA, H. LIBERSKA (red.), Psychologia rodziny (s. 21-45). Warszawa: PWN.

ŚwIERCZeK, A. (2010). Odpowiedzialne rodzicielstwo w nauczaniu Jana Pawla II. W: M. DuDA (red.), Odpowiedzialne rodzicielstwo wobec wyzwań XXI wieku (s. 13-29). Kraków: Wydawnictwo Św. Stanisława BM.

WóJCIK, M. (1999). Rodowód ojcostwa. Studia nad Rodzina, 3(2), 29-40. 
ZalewsKa, M. (1998). Dziecko $w$ autoportrecie z zamalowana twarza. Psychiczne mechanizmy zaburzeń rozwoju tożsamości dziecka głuchego i dziecka z opóźnionym rozwojem mowy. Warszawa: Wydawnictwo Jacek Santoski \& Co.

\title{
OJCOSTWO DZIECKA NIESŁYSZĄCEGO \\ Z PERSPEKTYWY PARADYGMATU EKOSYSTEMOWEGO
}

\author{
Streszczenie
}

Artykuł koncentruje się wokół teoretycznego ujęcia przeglądu literatury przedmiotu na temat ojcostwa dziecka niesłyszącego z perspektywy paradygmatu ekosystemowego. Zrozumienie istoty ojcostwa wymaga analizy w paradygmacie ekologicznym (uwzględniającym wpływ czynników środowiskowych: od mikro- do makrosystemowych) i w paradygmacie systemowym, w którym ważne jest poznanie sposobów i jakość interakcji między członkami rodziny a zewnętrznymi układami społecznymi. Przedstawiona analiza badań i refleksji naukowych pozwala dostrzec potrzebę udziału ojca w rozwoju psychospołecznym niesłyszącego dziecka w ciągu życia. Ponadto w kontekście podjętych rozważań można przyjąć tezę, że ojcostwo jest nie tylko czymś naturalnym dla człowieka funkcjonującego w grupie społecznej, lecz także wyrazem zrozumienia potrzeb wszystkich członków rodziny.

Słowa kluczowe: ojcostwo; dziecko niesłyszące; paradygmat ekosystemowy.

\section{THE FATHERING OF A DEAF CHILD FROM THE PERSPECTIVE OF THE ECOSYSTEM PARADIGM}

\section{S u m m a ry}

The article focuses on the theoretical approach to the review of literature on the subject of paternity of a deaf child from the perspective of the ecosystem paradigm. Understanding the nature of paternity requires analysis in the ecological paradigm (taking into account the impact of environmental factors: from micro- to macrosystem) and in the systemic paradigm in which it is important to know the ways and quality of interaction between family members and external social systems. The presented analysis of research and scientific reflection allows us to see the need for father's participation in the development of the psychosocial deaf child in the course of life. In addition, in the context of the considerations taken up, one can accept the thesis that paternity is not only something natural for a person functioning in a social group, but also an expression of understanding the needs of all family members.

Key words: fatherhood; deaf child; ecosystem paradigm. 